\title{
KEMAMPUAN MENULIS TEKS ANEKDOT DENGAN MENGGUNAKAN MODEL PEMBELAJARAN WRITE ARROUND PADA SISWA KELAS X SMK PUTRA JAYA STABAT
}

\author{
${ }^{1}$ Donny Syahputra, ${ }^{2}$ Sri Ulina Beru Ginting, \\ ${ }^{1}$ Mahasiswa STKIP Budidaya Binjai \\ doni63106@gmail.com \\ ${ }^{2}$ Dosen STKIP Budidaya Binjai \\ linaginting31@gmail.com
}

\begin{abstract}
ABSTRAK
Penelitian ini bertujuan untuk mengetahui kemampuan menulis teks anekdot dengan menggunakan model pembelajaran write aroundpada siswa kelas X SMK Putra Jaya Stabat tahun pelajaran 2020/2021. Jenis penelitian ini adalah penelitian deskriptif kuantitatif. Desain yang digunakan dalam penelitian ini yaitu desain one shot case study. Berdasarkan hasil analisis data dapat disimpulkan bahwa kemampuan menulis teks anekdot siswa dengan menggunakan model pembelajaran write arround berada pada tingkat kategori baik dengan nilai rata-rata sebesar 77, dan standar ketuntasan kelas mencapai $78 \%$. Jumlah siswa yang memiliki kemampuan menulis teks anekdot dengan kategori sangat baik sebanyak 8 orang atau 33,3\%, yang berada pada kategori baik sebanyak 12 orang atau 50\%, yang berada pada kategori cukup sebanyak 2 orang atau 8,3\%, yang berada pada kategori kurang sebanyak 2 orang atau 8,3\%, dan tidak ada siswa yang berada pada kategori sangat kurang.

Kata Kunci :Menulis, Teks Anekdot, Write Arround.
\end{abstract}

\section{ABSTRACT}

This study aims to determine the ability to write anecdotal texts using the write around learning model for class X students of SMK Putra Jaya Stabat in the 2020/2021 academic year. This type of research is a quantitative descriptive study. The design used in this study is a one shot case study design. Based on the results of the data analysis, it can be concluded that the students' ability to write anecdotal texts using the write around learning model is at the good category level with an average score of 77, and the standard of class completeness is $78 \%$. The number of students who have the ability to write anecdotal texts in the very good category is 8 people or 33.3\%, 12 people or $50 \%$ who are in the good category, 2 people or $8.3 \%$, who are in the good category. in the poor category as many as 2 people or $8.3 \%$, and there are no students who are in the very poor category.

Keywords: Writing Ability, Anecdotal Text, Write Arround.

\section{PENDAHULUAN}

Seseorang dalam berbahasa menurut Tarigan (2013:1) meliputi empat aspek dasar, yaitu "keterampilan menyimak, membaca, berbicara, dan menulis". Keterampilan atau kemampuan menulis bagi seorang siswa di sekolah merupakan suatu aspek keterampilan yang penting untuk dikembangkan.
Keterampilan menulis siswa akan berkembang jika dilatihkan secara terus menerus. Menurut Alwasilah (2005:42) "menulis tidak sesederhana dan semudah membalikan telapak tangan". Artinya agar memeiliki keterampilan menulis maka diperlukan praktik dan latihan berulang-ulang. 
Keterampilan menulis seseorang akan semakin baik apabila sudah terbiasa menulis. Sebaliknya jika seseorang tersebut malas dalam berlatih menulis, maka keterampilan menulis itu akan jauh dari penguasaannya. Menurut Tarigan (2013:4) "keterampilan menulis ini tidak akan datang secara otomatis tetapi harus melalui latihan dan praktik yang banyak dan teratur". Artinya keterampilan menulis seseorang akan dimilikinya dan menjadi lebih baik apabila banyak berlatih dan praktik secara teratur.

Guru menciptakan berbagai kesempatan yang memungkinkan siswa mengembangkan keterampilan menulis dalam proses pembelajaran di sekolah. Harapannya agar siswa dapat mengembangkan keterampilan mereka dalam menulis. Siswa yang terbiasa menulis, akan dapat melakukan komunikasi secara tertulis dengan baik dan memiliki tata bahasa yang sesuai dengan kaidah bahasa Indonesia. Kemudian seorang siswa yang dapat berkomunikasi dengan baik dan menguasai tata bahasa yang sesuai dengan kaidah bahasa, maka tidak sulit bagi mereka untuk menyalurkan ide, perasaan dan mekespresikan yang ada dalam diri mereka.

Perkembangan keterampilan berbahasa sangat diperlukan, karena bahasa merupakan dasar kemampuan siswa dalam meningkatkan kemampuan-kemampuan yang lain. Perhatian khusus dari orang tua ataupun guru sangat diperlukan dalam perkembangan bahasa tersebut. Tidak semua anak dapat belajar empat aspek berbahasa dengan mudah dan cepat, terutama perkembangan berbahasa anak dalam keterampilan menulis yang masih dalam kategori kurang. Menyikapi masalah tersebut, perlu diselenggarakannya kegiatan pembelajaran yang baik dan dapat meningkatkan keterampilan menulis siswa.

Menurut Asri (2005:20) "belajar merupakan suatu proses usaha yang dilakukan untuk merubah tingkah laku secara keseluruhan untuk berinteraksi dengan lingkungan". Sedangkan mengajar menurut Wassid (1987:1) "merupakan usaha menciptakan sistem lingkungan yang terdiri atas komponen mengajar, tujuan pengajaran, siswa, materi pelajaran, model pembelajaran pengajaran, dan media pembelajaran".

Kegiatan menulis merupakan kegiatan yang menghasilkan sebuah tulisan yang kemudian tulisan tersebut dapat dipahami oleh pembaca. Hal ini membuat seorang penulis harus perduli terhadap kejelasan apa yang ditulis, kekuatan tulisannya yang dapat mempengaruhi orang lain, dan kepiawaiannya dalam memilih dan mengolah kata-kata. Selain itu seorang penulis harus memiliki rasa percaya diri yang tinggi dan berani dalam menuliskan sesuatu.

Berdasarkan hasil observasi dan wawancara yang dilaksanakan oleh peneliti di SMK Putra Jaya Stabat, dengan guru mata pelajaran Bahasa Indonesia terkait kemampuan siswa dalam menulis teks anekdot pada kelas $\mathrm{X}$, mengatakan bahwa keterampilan siswa dalam menulis teks anekdot belum optimal. Hal tersebut tampak pada rendahnya keterampilan menulis 20 orang siswa pada materi menulis teks anekdot, dimana dari 20 siswa tersebut hanya $10 \%$ siswa yang mendapat nilai di atas KKM sebesar 75 dan terdapat $90 \%$ siswa yang mendapat nilai di bawah KKM. Masalah yang ada pada siswa yaitu siswa belum bisa membiasakan diri memiliki sikap percaya diri dalam menyampaikan ide atau gagasannya dalam bentuk tulisan. Selain itu kurangnya pembendaharaan kosa kata yang di miliki oleh siswa.

Menyikapi permasalahan tersebut maka salah satu alternatifnya adalah dengan menerapkan sebuah model pembelajaran yang dapat meningkatkan kemampuan menulis siswa. Model pembelajaran write arround adalah model pembelajaran yang dapat diterapkan dalam meningkatkan keterampilan menulis, sesuai dengan yang dinyatakan oleh Sulasmiana (2018:1) "penerapan model pembelajaran kooperatif tipe write a round dapat meningkatkan kemampuan menulis puisi siswa". Namun dalam hal ini, peneliti akan menggunkan model write around dalam pembelajaran menulis teks anekdot.

Model pembelajaran write around dilakukan secara berkelompok. Melalui kegitan kelompok, siswa akan saling memperhatikan 
dalam menuangkatkan ide dalam bentuk tulisan, sehingga siswa akan antusias dan memiliki kepercayaan diri dalam menuangkan ide atau gagasan pikirannya. Selain itu, dengan banyaknya gagasan dari setiap siswa dalam anggota kelompok dapat menambah pengetahuan dan perbendaharaan kata yang dimiliki siswa.

Model pembelajaran write arround adalah salah satu tipe pembelajaran kooperatif yang masing-masing anggota kelompoknya mendapat kesempatan untuk menulis dan mendapatkan stimulus untuk menulis. Menurut Fitri (2018:83) dengan menerapkan model write arround, "setiap anggota kelompok diharuskan untuk berpartisipasi dan secara bergiliran mengungkapkan gagasannya".

Tujuan utama penggunaan model pembelajaran write arround adalah agar siswa dapat menumbuhkan rasa senang dalam menulis dan mudah menuliskan apa yang menjadi pemikirannya. Hal ini karena dalam model pembelajaran write arround dapat membuat siswa akan saling membantu dalam menumbuhkan rangsangan untuk menulis melalui kalimat yang belum rampung.

Berdasarkan uraian pada latar belakang masalah di atas, peneliti tertarik ingin mengadakan sebuah penelitian terkait dengan kemampuan menulis siswa dan model pembelajaran write arround. Adapun judul penelitian ini yaitu "Kemampuan Menulis Teks Anekdot Dengan Menggunakan Model Pembelajaran Write Arround Pada Siswa Kelas X SMK Putra Jaya Stabat Tahun Pelajaran 2020/2021."

\section{METODOLOGI PENELITIAN}

Lokasi penelitian merupakan tempat dilaksanakannya peneltian. Dalam penelitian ini akan di laksanakan di SMK_PP Putra Jaya Stabat yang beralamat di Jalan Wonosari No. 59 Desa Perdamaian, Kecamatan Stabat, Kabupaten Langkat, Provinsi Sumatera Utara.Penelitian ini nantinya akan dilaksanakan pada semester ganjil tahun pelajaran 2020/2021.

Populasi menurut Sugiyono (2012:57) adalah "subyek atau obyek yang ditetapkan peneliti untuk di pelajari dan kemudian ditarik kesimpulannya". Berdasarkan pendapat tersebut populasi dalam penelitian ini adalah seluruh siswa kelas X SMK_PP Putra Jaya Stabat tahun pelajaran 2020/2021 sebanyak 240 siswa. Seperti yang ditunjukkan pada tabel berikut.

Menurut Arikunto (2018:174) "sampel adalah sebagaian atau wakil populasi yang diteliti". Adapun cara menentukan sampel yang peneliti lakukan adalah apabila jumlah subyeknya besar dapat diambil antara $10-15 \%$, atau 20-25\% atau lebih (Arikunto, 2018:174).Berdasarkan pendapat di atas, maka jumlah sampel dalam penelitian ini yaitu 24 orang siswa

Karena dalam penelitian ini akan mendeskripsikan kemampuan menulis teks anekdot dengan menggunakan modelpembelajaran write aroundmaka jenis penelitian ini adalah termasuk penelitian deskriptif. Desain yang digunakan dalam penelitian ini yaitu desainone shot case study. Menurut Arikunto (2018:124),desain one shot case studyadalah "peneliti mengadakan treatment satu kali kemudian diadakan postest. Dari hasil postest diambil kesimpulan dengan cara melihat rata-rata hasil dan membandingkannya dengan standar yang diinginkan". Berdasarkan pendapat tersebut peneliti akan memberikan perlakuan pembelajaran dengan menggunakan modelpembelajaran write aroundpada sampel penelitian, kemudian peneliti akan memberikan postest kemampuan menulis teks anekdot dan data hasil postest akan dianalisis guna menarik kesimpulan sesusai dengan standar yang telah ditetapkan oleh peneliti.

\section{A. Instrumen Penelitian}

Menurut Chaer (2007:37) "untuk mengambil data diperlukan alat pengambil data yang disebut dengan instilah instrumen penelitian". Instrumen penelitian dalam penelitian ini adalah tes. Lembar tes digunakan untuk mengukur kemampuan siswa dalam menulis teks anekdot. Kriterian penilaian untuk menilai kemampuan menulis teks anekdot siswa ditumjukkam pada tabel berikut. 
Tabel 1. Indikator Penilaian Kemampuan Menulis Teks Anekdot

\begin{tabular}{clcc} 
No & \multicolumn{2}{c}{ Indikator Penilaian } & Nilai \\
\hline 1. & $\begin{array}{l}\text { Isi teks anekdot terdapat } \\
\text { sindiran, kritik, humor, dan }\end{array}$ & \\
perilaku. & & \\
\hline $\begin{array}{l}\text { Jika salah satu aspek tidak } \\
\text { tercantum dalam menulis }\end{array}$ & 30 \\
anekdot. & & \\
\hline Jika dua aspek tidak & 20 \\
tercantum dalam menulis \\
anekdot.
\end{tabular}

Jika tiga aspek tidak 10
tercantum dalam menulis
anekdot.

Jika empat aspek tidak 5 tercantum dalam menulis anekdot.

2. Struktur anekdot lengkap 30 yang terdiri atas abstrak, orientasi, krisis, reaksi, dan koda.

Jika salah satu aspek tidak 20 tercantum dalam menulis anekdot.

Jika dua aspek tidak 15 tercantum dalam menulis anekdot.

Jika tiga aspek tidak 10
tercantum dalam menulis anekdot.

Jika empat aspek tidak 5
tercantum dalam menulis anekdot.

3. Pengembangan sesuai 30
dengan beberapa aspek seperti ketepatan tanda baca, ketepatan ejaan, penggunaan diksi yang tepat, konjungsi yang tepat, dan struktur kalimat yang efektif.

\begin{tabular}{llrl}
\hline $\begin{array}{l}\text { Jika salah satu aspek tidak } \\
\text { tercantum }\end{array}$ dalam menulis & \\
anekdot. & & & \\
\hline Jika dua & aspek tidak & 15 \\
tercantum dalam menulis & \\
anekdot. & & & \\
\hline Jika tiga aspek tidak & 10 \\
tercantum dalam menulis & \\
anekdot. & & &
\end{tabular}

Jika empat aspek tidak 5 tercantum dalam menulis anekdot.

Untuk mengetahui kategori nilai yang diperoleh siswa sebagai hasil menulis teks anekdot. Dapat digunakan kategori nilai sebagai berikut.

Tabel 2. Kategori Penilaian Kemampuan Menulis Teks Anekdot

\begin{tabular}{ccc} 
Kategori & Rentang Nilai & Huruf \\
\hline Sangat Baik & $85-100$ & A \\
\hline Baik & $70-84$ & B \\
\hline Cukup & $60-69$ & C \\
\hline Kurang & $50-59$ & D \\
\hline $\begin{array}{c}\text { Sangat Kurang } \\
\text { Sumber : Sudijono }(2008: 24)\end{array}$ & E
\end{tabular}

\section{B. Prosedur Penelitian}

Adapun prosedur penelitian yang akan dilaksanakan adalam penelitian ini adalah sebagai berikut:

1. Persiapan Penelitian

a. Mengurus surat izin penelitian oleh kampus.

b. Mempersiapkan rencana pelaksanaanp pembelajaran (RPP), dan lembar tes menulis teks anekdot.

2. Pelaksanaan Penelitian

a. Melaksanakan kegiatan pembelajaran.

b. Memeberikan tes kemampuan menulis teks anekdot.

\section{Analisis Data}

a. Mengolah data hasil penelitian.

b. Menyusun laporan hasil penelitian.

c. Menyimpulkan hasil penelitian.

\section{Teknik Pengumpulan Data}

Menurut Arikunto (2018:266) "untuk mengukur ada atau tidaknya serta besarnya kemampuan objek yang diteliti dapat digunakan tes". Teknik pengumpulan data dalam penelitian yaitu dengan memberikan tes kepada sampel penelitian. Tes tersebut digunakan untuk mengetahui kemampuan siswa dalam menulis teks anekdot setelah diberikan treathmentatau perlakuan.

\section{Teknik Analisis Data}

Data yang telah terkumpul selanjutnya akan dianalisis untuk dapat melakukan penarikan kesimpulan. Langkah-langkah 
analisis tersebut dapat dilakukan dengan cara sebagai berikut :

a. Menghitung skor/nilai yang diperoleh setiap siswa.

b. Mencari nilai mean/rata-rata dengan rumus sebagai berikut :

$\bar{x}=\frac{\sum x_{i}}{n} \quad$ (Sumber $:$ Sudjana, 2005:63)

Keterangan :

$\bar{x}=$ Nilai rata-rata

$\sum_{x_{i}}=$ Jumlah skor total

$\mathrm{n}=$ Jumlah sampel

c. Menentukan standar ketuntasan kelas, untuk mengetahui standar ketuntasan kelas dapat digunakan rumus berikut :

$\mathrm{PKK}=\frac{X}{N} \times 100 \% \quad$ (Sumber:

Sudijono, 2008:75)

Keterangan :

PKK : Persentase Ketuntasan Klasikal.

$\mathrm{X}$ : Jumlah siswa yang telah tuntas.

$\mathrm{N}$ : Jumlah seluruh siswa .

Dengan kriteria:

PKK $<70 \%$ : Ketuntasan belajar klasikal belum tercapai.

PKK $\geq 70 \%$ : Ketuntasan Belajar klasikal telah tercapai.

Berdasarkan keterangan diatas dan nilai kriteria ketuntasan minimal sebesar 75 , maka standar ketuntasan kelasyang ditetapkan dalam penelitian ini adalah jika di dalam kelas sampel penelitian terdapat $\geq$ $70 \%$ siswa yang mencapai nilai $\geq 75$.

\section{HASIL DAN PEMBAHASAN}

Penelitian ini telah dilaksanakan di SMK_PP Putra Jaya Stabat dengan jumlah populasi sebanyak 240 orang siswa dan jumlah sampel penelitian sebanyak 24 orang siswa yang merupakan kelas $\mathrm{X}$ tahun pelajaran 2020/2021. Hasil penelitian ini akan menyajikan kemampuan menulis teks anekdot siswa setelah mengikuti proses pembelajaran dengan model pembelajaran write arround. (Menurut Gulo \& M. Ali). Kemampuan berbahasa yang harus dimiliki oleh sisa ialah kemampuan menulis. Deskripsi kemampuan menulis teks anekdot siswa dalam penelitian ini didasarkan pada tiga aspek penilaian yaitu aspek isi, struktur dan kebahasaan. Adapun nilai kemampuan menulis teks anekdot siswa berdasarkan hasil penelitian ini dapat dilihat pada tebel berikut.

Tabel 3. Nilai Kemampuan Menulis Teks Anekdot Siswa

\begin{tabular}{ccccc} 
Kode & \multicolumn{3}{c}{ Aspek Penilaian } & Nilai \\
\cline { 2 - 5 } Siswa & Isi & Struktur & Kebahasaan & \\
\hline A1 & 30 & 30 & 30 & 90 \\
\hline A2 & 30 & 30 & 30 & 90 \\
\hline A3 & 30 & 30 & 30 & 90 \\
\hline A4 & 30 & 30 & 30 & 90 \\
\hline A5 & 40 & 30 & 20 & 90 \\
\hline A6 & 40 & 15 & 30 & 85 \\
\hline A7 & 40 & 30 & 15 & 85 \\
\hline A8 & 40 & 15 & 30 & 85 \\
\hline A9 & 30 & 20 & 30 & 80 \\
\hline A10 & 30 & 20 & 30 & 80 \\
\hline A11 & 20 & 30 & 30 & 80 \\
\hline A12 & 20 & 30 & 30 & 80 \\
\hline A13 & 20 & 30 & 30 & 80 \\
\hline A14 & 30 & 15 & 30 & 75 \\
\hline A15 & 30 & 30 & 15 & 75 \\
\hline A16 & 30 & 30 & 15 & 75 \\
\hline A17 & 30 & 15 & 30 & 75 \\
\hline A18 & 30 & 30 & 15 & 75 \\
\hline A19 & 20 & 30 & 20 & 70 \\
\hline A20 & 20 & 30 & 20 & 70 \\
\hline A21 & 20 & 15 & 30 & 65 \\
\hline A22 & 30 & 20 & 15 & 65 \\
\hline A23 & 10 & 15 & 30 & 55 \\
\hline A24 & 10 & 20 & 20 & 50 \\
\hline 660 & 590 & 605 & 1855 \\
& Berdasarkan & nilai & kemampuan
\end{tabular}

menulis teks anekdot siswa di atas, selanjutnya dapat dideskripsikan uraian sebagai berikut.

\section{Kemampuan Menulis Teks Anekdot Siswa Pada Seluruh Aspek}

Untuk mengetahui kemampauan menulis teks anekdot siswa pada seluruh aspek (isi, strukutur, dan kebahasaan) dapat dilihat berdasarkan hasil perhitungan nilai rata-ratanya. Dari 24 orang sampel penelitian telah diketahui bahwa jumlah nilai pada seluruh aspek adalah sebesar 1855 maka nilai rata-rata dan tingkat kemampuannya adalah sebagai berikut: 
$\bar{x}=\frac{\sum x_{i}}{n}=\frac{1855}{24}=77,29=77$

Berdasarkan hasil perhitungan nilai rata-rata di atas dapat diketahui bahwa nilai tersebut berada pada rentang nilai 70-84 dengan kategori baik. Artinya tingkat kemampuan siswa dalam menulis teks anekdot pada seluruh aspek setelah mengikuti proses pembelajaran dengan model pembelajaran write arround sudah baik. Untuk mengetahui persentase ketuntasan klasikal dihitung dengan menggunakan rumus berikut:

$\mathrm{PKK}=\frac{X}{N} \times 100 \%=\frac{18}{24} \times 100 \%=75 \%$

Berdasarkan hasil perhitungan persentase ketuntasan klasikal dapat diketahui bahwa standar ketuntasan kelas yang ditetapkan dalam penelitian ini dapat tercapai sebab terdapat $\geq 70 \%$ siswa yang mencapai nilai $\geq 75$. Kemudian untuk mengetahui klasifikasi nilai kemampuan menulis teks anekdot siswa dapat dilihat pada tabel berikut.

Tabel 4. Klasifikasi Nilai Kemampuan Menulis Teks Anekdot Siswa

\begin{tabular}{cccl}
$\begin{array}{c}\text { Rentang } \\
\text { Nilai }\end{array}$ & Kategori & $\begin{array}{c}\text { Jumlah } \\
\text { Siswa }\end{array}$ & Persentase \\
\hline $85-100$ & $\begin{array}{c}\text { Sangat } \\
\text { Baik }\end{array}$ & 8 & $33.3 \%$ \\
\hline $70-84$ & Baik & 12 & $50 \%$ \\
\hline $60-69$ & Cukup & 2 & $8.3 \%$ \\
\hline $50-59$ & Kurang & 2 & $8.3 \%$ \\
\hline $0-49$ & $\begin{array}{c}\text { Sangat } \\
\text { Kurang }\end{array}$ & 0 & $0 \%$
\end{tabular}

Berdasankan tabel di atas, diketahu bahwa jumlah siswa yang memiliki kemampuan menulis teks anekdot dengan kategori sangat baik sebanyak 8 orang atau $33,3 \%$, yang berada pada kategori baik sebanyak 12 orang atau 50\%, yang berada pada kategori cukup sebanyak 2 orang atau $8,3 \%$, yang berada pada kategori kurang sebanyak 2 orang atau $8,3 \%$, dan tidak ada siswa yang berada pada kategori sangat kurang.

\section{Kemampuan Menulis Teks Anekdot} Siswa Pada Aspek Isi

Kemampauan menulis teks anekdot siswa pada aspek isi dapat dilihat dari hasil perhitungan nilai rata-ratanya. Dari 24 orang sampel penelitian telah diketahui bahwa jumlah nilai pada aspek isi adalah sebesar 660 maka nilai ratarata dan tingkat kemampuannya adalah sebagai berikut:

$\bar{x}=\frac{\sum x_{i}}{n}=\frac{660}{24}=27,5=28$

Skor atau nilai maksimal pada aspek isi adalah sebsesar 40, maka dapat diketahui tingkat kemampuan menulis teks anekdot siswa pada aspek isi dengan menggunakan rumus indeks prestasi kelas sebagai berikut:

$\mathrm{IPK}=\frac{\bar{x}}{\text { Skor }_{\text {maks }}} \times 100=\frac{27,5}{40} \times 100=$ $68,75=69$

Berdasarkan hasil perhitungan indeks prestasi kelas pada aspek isi dapat diketahui bahwa nilai indeks tersebut berada pada rentang nilai 60-69 dengan kategori cukup. Artinya tingkat kemampuan siswa dalam menulis teks anekdot pada aspek isi setelah mengikuti proses pembelajaran dengan model pembelajaran write arround cukup baik.

3. Kemampuan Menulis Teks Anekdot Siswa Pada Aspek Struktur

Untuk mengetahui kemampauan menulis teks anekdot siswa pada aspek struktur dapat dilihat berdasarkan hasil perhitungan nilai rata-ratanya. Dari 24 orang sampel penelitian telah diketahui bahwa jumlah nilai pada aspek struktur adalah sebesar 590 maka nilai rata-rata dan tingkat kemampuannya adalah sebagai berikut:

$\bar{x}=\frac{\sum x_{i}}{n}=\frac{590}{24}=24,58=25$

Skor atau nilai maksimal pada aspek struktur adalah sebsesar 30, maka dapat diketahui tingkat kemampuan menulis teks anekdot siswa pada aspek struktur dengan menggunakan rumus indeks prestasi kelas sebagai berikut:

IPK $=\frac{\bar{x}}{\text { Skor }_{\text {maks }}} \times 100=\frac{24,58}{30} \times 100=$ $81,94=82$

Berdasarkan hasil perhitungan indeks prestasi kelas pada aspek isi dapat diketahui bahwa nilai indeks tersebut berada pada rentang nilai 70-84 dengan 
kategori baik. Artinya tingkat kemampuan siswa dalam menulis teks anekdot pada aspek struktur setelah mengikuti proses pembelajaran dengan model pembelajaran write arround sudah baik.

\section{Kemampuan Menulis Teks Anekdot} Siswa Pada Aspek Kebahasan

Untuk mengetahui kemampauan menulis teks anekdot siswa pada aspek kebahasaan dapat dilihat berdasarkan hasil perhitungan nilai rata-ratanya. Dari 24 orang sampel penelitian telah diketahui bahwa jumlah nilai pada aspek kebahasaan adalah sebesar 605 maka nilai rata-rata dan tingkat kemampuannya adalah sebagai berikut:

$\bar{x}=\frac{\sum x_{i}}{n}=\frac{605}{24}=25,21=25$

Skor atau nilai maksimal pada aspek kebahasaan adalah sebsesar 30, maka dapat diketahui tingkat kemampuan menulis teks anekdot siswa pada aspek kebahasaan dengan menggunakan rumus indeks prestasi kelas sebagai berikut:

$$
\begin{aligned}
\text { IPK } & =\frac{\bar{x}}{\text { Skor } m a k s} \times 100=\frac{25,21}{30} \times 100= \\
84,03 & =84 \\
& \text { Berdasarkan hasil perhitungan }
\end{aligned}
$$
indeks prestasi kelas pada aspek isi dapat diketahui bahwa nilai indeks tersebut berada pada rentang nilai 70-84 dengan kategori baik. Artinya tingkat kemampuan siswa dalam menulis teks anekdot pada aspek kebahasaan setelah mengikuti proses pembelajaran dengan model pembelajaran write arround sudah baik.

\section{KESIMPULAN}

\section{A. Kesimpulan}

Berdasarkan hasil penelitian mengenai kemampuan menulis teks anekdot dengan menggunakan model pembelajaran write arround pada siswa kelas X SMK Putra Jaya Stabat tahun pelajaran 2020/2021 dapat disimpulkan bahwa kemampuan menulis teks anekdot siswa dengan menggunakan model pembelajaran write arround berada pada tingkat kategori baik dengan nilai ratarata sebesar 77 dan standar ketuntasan kelas mencapai $78 \%$. Jumlah siswa yang memiliki kemampuan menulis teks anekdot dengan kategori sangat baik sebanyak 8 orang atau $33,3 \%$, yang berada pada kategori baik sebanyak 12 orang atau $50 \%$, yang berada pada kategori cukup sebanyak 2 orang atau $8,3 \%$, yang berada pada kategori kurang sebanyak 2 orang atau $8,3 \%$, dan tidak ada siswa yang berada pada kategori sangat kurang.

\section{B. Saran}

Berdasarkan hasil penelitian yang dilaksanakan mengenai kemampuan menulis teks anekdot dengan menggunakan model pembelajaran write arround pada siswa kelas X SMK Putra Jaya Stabat tahun pelajaran 2020/2021, dapat disampaikan saran-saran sebagai berikut:

a. Model pembelajaran write arround dapat dimanfaatkan atau digunakan oleh guru bahasa Indonesia sebagai alternatif model pembelajaran dalam meningkatkan kemampuan menulis teks anekdot siswa.

b. Agar penerapan model pembelajaran write arround dapat berjalan secara efektif dan efisien maka perlu didukung oleh kemampuan guru dalam mengkondisikan kelas dan mengimplementasikan langkahlangkahnya.

c. Guru sebaiknya lebih kreatif dan inovatif dalam menciptakan metode strategi pembelajaran, agar kegiatan pembelajaran dapat berlangsung lebih menyenangkan dan bermakna.

d. Penggunaan model pembelajaran write arround seyogyanya dapat diterapkan secara berkesinambungan oleh guru dalam pembelajaran bahasa Indonesia.

\section{DAFTAR PUSTAKA}

Astuti, Siwi Puji. 2015. "Pengaruh Kemampuan Awal Dan Minat Belajar Terhadap Prestasi Belajar Fisika". Jurnal Formatif No. 5 Vol. 1.

Dalman. 2014. Keterampilan Menulis. Jakarta: PT Raja Grafindo Persada 
Fatimah, Nuraini. 2013. “Teks Anekdot Sebagai Sarana Pengembangan Kompetensi Bahasa dan Karakter Siswa”.Jurnal Pendidikan Bahasa, Sastra Indonesia, dan Daerah FKIP Universitas Muhammadiyah Surakarta.

Fitri, Rahayu. 2018. "Perbedaan Penggunaan Pendekatan Kooperatif Tipe Round Table Dan Write Around Terhadap Kemampuan Menulis Teks Cerpen”. Jurnal Inovasi Pembelajaran. Volume 4, Nomor 1.

Gulo, sudarman. M. ali Sidiqin. Kemampuan Menulis Teks Anekdot Dengan Mengggunakan Media Gambar Oleh Siswa Kelas X SMK Swasta YPIS Maju Binjai Tahun Pelajaran 2019/2020. Jurnal.

Juliansyah, Noor. 2013. Metodologi Penelitian. Jakarta : Kencana Prenada Media Group.

Komalasari, Kokom. 2011 . Pembelajaran Kontekstual Konsep dan Aplikasi.Bandung: PT Refika Aditama.

Kosasih, Engkos. 2016. Cerdas Berbahasa Indonesia: untuk SMA/MA Kelas X. Jakarta: Penerbit Erlangga.

Muhammad Fathurrohman. 2015. ModelModel Pembelajaran Inovatif. Jogjakarta:Ar-Ruzz Media.

Nurgiantoro, Burhan. 2017. Penilaian Pembelajaran Bahasa Berbasis Kompetensi. Yogyakarta: BPFE.

Pramesty, Fanny Indah. 2017."Pengaruh Model Pembelajaran Kooperatif Tipe Write Around Terhadap Keterampilan Menulis Eksposisi Siswa Kelas V SDN Di Kecamatan Pakal". Jurnal PGSD, Volume 5 Nomor 3.

Pudjiono Setyawan. tt. Konsep Dasar Menulis. Yogyakarta: Staff Site UNY.
Sugiyono. 2012. Metode Penelitian Pendidikan.Jakarta : Alfabeta.

Suherli, dkk. 2017. Buku Guru: Bahasa Indonesia. Jakarta: Kemendikbud.

Sulasmiana. 2018. "Penerapan Model Pembelajaran Kooperatif Tipe Write Around Untuk Meningkatkan Kemampuan Menulis Puisi Siswa Kelas V SD Negeri 5 Tanjung Punak". Jurnal Online Mahasiswa. Vol. 5, No. 1.

Suprijono, Agus. 2011.Model-Model Pembelajaran. Jakarta: Gramedia Pustaka Jaya.

Tarigan, Henry Guntur. 2017.Menulis sebagai Suatu Keterampilan Berbahasa.Bandung : Angkasa.

Trianto. 2019. Mendesain Model Pembelajaran Inovatif-Progresif. Jakarta: Kencana Prenada Media Group 